\title{
Contamination of public parks in Presidente Prudente (Sáo Paulo, Brazil) by Toxocara spp. eggs
}

\author{
Contaminação de praças públicas de Presidente Prudente, São Paulo, Brasil, por ovos de Toxocara spp. \\ Vamilton Alvares Santarém ${ }^{1 *}$; Vanessa Cristina Pereira ${ }^{2}$; Beatriz Cristina Porto Alegre² \\ ${ }^{1}$ Laboratory of Preventive Veterinary Medicine II (Animal Parasitology), Veterinary Teaching Hospital, \\ Universidade do Oeste Paulista - Unoeste, Presidente Prudente, SP, Brazil \\ ${ }^{2}$ Veterinary Medicine Course, Universidade do Oeste Paulista - Unoeste, Presidente Prudente, SP, Brazil
}

Received October 20, 2011

Accepted March 20, 2012

\begin{abstract}
This study aims to evaluate soil contamination by Toxocara spp. eggs in public parks in Presidente Prudente, São Paulo, Brazil. Soil samples (500 g) were collected every month over a 12-month period, from 25 parks in different parts of the city (northern, southern, eastern, western and central areas). Two 10-g aliquots of the material collected from each park were subjected to the centrifuge-flotation method to recover Toxocara spp. eggs. Twenty-four out of the 25 squares studied (96.0\%) were contaminated and the number of eggs recovered ranged from 1 to 398 per sample. Eggs were recovered all over the year. Despite the number being greater in autumn $(\mathrm{p}<0.001)$, there was no correlation between number egg number and average monthly temperature $(r=-0.492 ; p=0.148)$ or between egg number and monthly rainfall $(r=-0.299 ; p=0.402)$. Park localization does not influence egg presence $(p=0.7116)$. Because of the high level of contamination of the parks by Toxocara spp. eggs, prevention of contamination of public areas by larva migrans agents is indicated.
\end{abstract}

Keywords: Environment contamination, epidemiology, toxocariasis, larva migrans.

\section{Resumo}

O objetivo do estudo foi avaliar a contaminação do solo de praças públicas por ovos de Toxocara spp. em Presidente Prudente, São Paulo. Amostras de solo $(500 \mathrm{~g})$ foram coletadas mensalmente, durante um período de 12 meses, de 25 praças de cinco diferentes setores da cidade (norte, sul, leste, oeste e central). Duas alíquotas de $10 \mathrm{~g}$ do material coletado foram submetidas ao método de centrífugo-flutuação (sulfato de zinco; $\mathrm{d}=1.200 \mathrm{~g} / \mathrm{cm}^{3}$ ), para recuperação dos ovos. Das 25 praças estudadas, 24 (96,0\%) estavam contaminadas e o número variou de 1 a 398 ovos por amostra analisada. A recuperaçáo foi verificada durante todos os meses do ano, sendo maior no outono $(\mathrm{p}<0,001)$. Entretanto, não houve correlação entre o número de ovos e a temperatura média $(r=-0,492 ; \mathrm{p}=0,148)$ e a precipitação pluviométrica $(\mathrm{r}=-0,299 ; \mathrm{p}=0,402)$ mensal. Não houve influência da localização dos parques sobre a quantidade de ovos $(\mathrm{p}=0,7116)$. Devido ao alto nível de contaminação de parques públicos por ovos de Toxocara spp., a prevençáo da contaminação de áreas públicas pelos agentes de larva migrans é indicada.

Palavras-chave: Contaminação ambiental, epidemiologia, toxocaríase, larva migrans.

Despite inclusion on the list of neglected diseases, human toxocariasis (ocular/visceral larva migrans) is one of the most widespread geohelminth zoonotic diseases in both disadvantaged and developed countries. Human infection is most commonly caused by accidental ingestion of larvated Toxocara spp. eggs that are present in contaminated environments, particularly soil

\footnotetext{
${ }^{*}$ Corresponding author: Vamilton Alvares Santarém

Laboratório de Medicina Veterinária Preventiva (Parasitologia),

Hospital Veterinário, Universidade do Oeste Paulista - Unoeste,

Rod. Raposo Tavares, Km 572, Bairro Limoeiro, CEP 19067-175,

Presidente Prudente, SP, Brasil

e-mail: vamilton@unoeste.br
}

in public areas such as parks and gardens that are frequented by dogs, cats and humans (SANTARÉM et al., 2011).

In Brazil, several studies over the last decade have demonstrated contamination of public places by Toxocara spp. eggs (CAPUANO; ROCHA, 2005; SANTARÉM et al., 2010; CASSENOTE et al., 2011). Previous studies have considered that contact with soil is a risk factor for toxocariasis in humans. Thus, the presence of environmental contamination is considered to be the best risk indicator for Toxocara spp. infection of human populations.

The aim of this study was to evaluate the influence of climate, season and geographical location on the presence of Toxocara spp. eggs in public parks in Presidente Prudente, state of São Paulo, Brazil. 
Presidente Prudente ( $22^{\circ} 10^{\prime} 30^{\prime \prime} \mathrm{S}$ and $\left.51^{\circ} 25^{\prime} 28^{\prime \prime} \mathrm{W}\right)$ is the biggest city in the western part of the state of São Paulo, and its current population is approximately 220,000. The city has 47 public parks, and 44 of them contain children's playgrounds. In order to study soil contamination, five parks from each of different areas of the municipality (central, southern, northern, eastern and western areas) were randomly selected, thus totaling 25 (53.2\%) out of the 47 squares. A total of $500 \mathrm{~g}$ of soil was sampled every month, between March 2010 and February 2011. To recover Toxocara spp. eggs, a technique described elsewhere was used (SANTARÉM et al., 2009). The Kruskal-Wallis test was used to compare the number of eggs in different areas, months and seasons, while Spearman's correlation was used to evaluate the influence of temperature $\left({ }^{\circ} \mathrm{C}\right)$ and rainfall $(\mathrm{mm})$ on the number of eggs.

It was observed that $96 \%(24 / 25)$ of the studied parks were contaminated by at least one Toxocara spp. egg. The numbers of eggs recovered ranged from 1 to 398 within the same sample. The contamination observed in this study was higher than what had previously been observed in other studies carried out in Brazil (SANTARÉM et al., 2010; CASSENOTE et al., 2011).

It has been stated that environmental and technical factors, such as the type of soil and the technique used for egg recovery, presumably influence the recovery of ascarid eggs from environmental samples (NUNES et al., 1994; SANTARÉM et al., 2009). Consequently, these factors can influence the process of egg recovery, which creates difficulties in comparing the results from different investigations.

Egg recovery was observed in all the months of the year. A higher number of eggs was observed in the autumn $(\mathrm{p}<0.001)$ (Table 1). No correlation was found between the number of eggs recovered and the average monthly temperature $(r=-0.492$; $\mathrm{p}=0.148$ ) or between the number of eggs and the monthly rainfall $(\mathrm{r}=-0.299 ; \mathrm{p}=0.402)$. Seasonal fluctuation may also influence the recovery of eggs from soil samples (CHIEFFI; MÜLLER, 1976; QUEIROZ et al., 2006). Nevertheless, in southern Brazil, there are no difference between the numbers of eggs recovered in summer and winter (TIYO et al., 2008). In the present study, eggs were detected throughout the year, but the recovery rate was significantly higher in autumn, in contrast with some studies carried out in south Brazil. Chieffi and Müller (1976) observed the greater contamination in winter and spring, while Gallina et al. (2011) verified the greatest incidence of parasites in the spring.

Viable eggs were observed in 183 (61\%) out of the 300 samples analyzed. Larvated eggs were observed in eight out of $183(4.4 \%)$, while embryonated eggs were recovered in 175 samples $(95.6 \%)$.

Table 1. Mean numbers of Toxocara spp. eggs \pm standard deviation (SD) in 25 public parks $s$ in from the municipality of Presidente Prudente (São Paulo, Brazil), between March 2010 and February 2011, according to the seasons.

\begin{tabular}{lrc}
\hline \multicolumn{1}{c}{ Season } & Mean \pm SD & 95\% Confidence Interval \\
\hline Autumn & $13.0^{\mathrm{A}} \pm 28.0$ & $0.6310-23.742$ \\
Winter & $0.51^{\mathrm{B} *} \pm 0.74$ & $0.2012-0.8121$ \\
Spring & $0.32^{\mathrm{B} *} \pm 0.41$ & $0.1492-0.4908$ \\
Summer & $0.08^{\mathrm{B} * *} \pm 0.28$ & $-0.0343-0.1943$ \\
\hline
\end{tabular}

Means followed by different letters are significantly different. Kruskal-Wallis test $\left({ }^{*} \mathrm{p}<0.01 ;{ }^{* *} \mathrm{p}<0.001\right)$.
These data suggest that the soil composition and climatic factors may have a positive influence on the viability of the eggs in the environment. According to Nunes et al. (1994), the distribution of ascarid eggs is more homogeneous in sandy soil, which was the most common type of soil observed in the children's playgrounds where the samples were collected.

Regarding the frequencies of eggs in the parks in different areas, taking into account the season, the highest average count was found in the eastern zone. Egg recovery was significantly higher in the autumn in all the areas studied ( $<<0.01)$, excluding the southern area. No significant difference was seen in comparing the average numbers of eggs obtained from the five areas in the same month $(p=0.7116)$. There is some controversy regarding the influence of sampling location on soil contamination. In this study, there was no significant correlation between the average number of eggs and the locations of the parks. On the other hand, in other studies carried out in Brazil, the highest frequency of contamination was present in parks located on the outskirts (CHIEFFI; MÜLLER, 1976; COELHO et al., 2001; SANTARÉM et al., 2010). Thus, it is possible that climatic factors influenced the conditions for maintaining the eggs throughout the year.

Ancylostomatidae eggs ( $\mathrm{n}=15)$ were recovered in $12(48 \%)$ of the studied parks, ranging from 1 to 2 eggs per sample. Recovery of both Ancylostomatidae and Toxocara spp. eggs in the soil samples points towards free access by pets, with consequent contamination of the soil. Access by dogs and cats to the parks may influence the degree of soil contamination by Toxocara spp. eggs. Cassenote et al. (2011) observed that the frequency of geohelminth findings in fenced parks (11.1\%) was significantly lower than in non-fencedoff areas $(45.3 \%)$. In the present investigation, it was seen that pets had access to the parks, even those that were fenced.

The climatic conditions of Presidente Prudente and the characteristics of the soil in its parks are favorable for maintenance of Toxocara spp. eggs throughout the year. In addition, the frequency of eggs together with the free access of pets to the parks creates an important resource for infection of population by agents of larva migrans.

\section{Acknowledgements}

To the São Paulo Research Foundation (FAPESP) for the fellowship to Vanessa Cristina Pereira (Process number 2009/183614). To the Unoeste Meteorological Center for providing the meteorological data.

\section{References}

Capuano DM, Rocha GM. Environmental contamination by Toxocara sp. eggs in Ribeirão Preto, São Paulo, Brazil. Rev Inst Med Trop São Paulo 2005; 47(4): 223-226. PMid:16138206. http://dx.doi. org/10.1590/S0036-46652005000400009

Cassenote AJF, Pinto Neto JM, Lima-Catelani ARA, Ferreira, AW. Contaminaçáo do solo por ovos de geo-helmintos com potencial zoonótico na municipalidade de Fernandópolis, Estado de São Paulo, entre 2007 e 2008. Rev Soc Bras Med Trop 2011; 44(3): 371-374. PMid:21552740. http://dx.doi.org/10.1590/S0037-86822011005 
Chieffi PP, Müller EE. Prevalence of parasitic diseases by Toxocara canis in dogs, and the finding of eggs of Toxocara species in the soil of public places in the urban area of Londrina, State of Paraná, Brazil. Rev Saúde Pública 1976; 10(4): 367-372. PMid:1019565. http://dx.doi. org/10.1590/S0034-89101976000400010

Coelho LMPS, Dini CY, Milman MHSA, Oliveira SM. Toxocara spp. eggs in public squares of Sorocaba, São Paulo state, Brazil. Rev Inst Med Trop São Paulo 2001; 43(4): 189-191. PMid:11557996. http://dx.doi. org/10.1590/S0036-46652001000400002

Gallina T, Silva MAMP, Castro LLD, Wendt EW, Villela MM, Berne MEA. Presence of eggs of Toxocara spp. and hookworms in a student environment in Rio Grande do Sul, Brazil. Rev Bras Parasitol Vet 2011; 20(2): 176-177. PMid:21722496

Nunes CM, Sinhorini IL, Ogassawara S. Influence of soil texture in the recovery of Toxocara canis eggs by a flotation method. Vet Parasitol 1994; 53(3-4): 269-274. PMid:7975122. http://dx.doi. org/10.1016/0304-4017(94)90190-2

Queiroz ML, Simonsen M, Paschoalotti MA, Chieffi PP. Frequency of soil contamination by Toxocara canis eggs in the south region of São
Paulo municipality (SP, Brazil) in an 18-month period. Rev Inst Med Trop São Paulo 2006; 48(6): 317-319. PMid:17221127. http://dx.doi. org/10.1590/S0036-46652006000600003

Santarém VA, Felix A, Rodenas RS, Assis APD, Da Silva AV. Contaminação por ovos de Toxocara spp. em praças públicas das regiōes central e periurbana de Mirante do Paranapanema, São Paulo, Brasil. Vet Zoot 2010; 17(1): 47-53.

Santarém VA, Magoti LP, Sichieri TD. Influence of variables on centrifuge-flotation technique for recovery of Toxocara canis eggs from soil. Rev Inst Med Trop São Paulo 2009; 51(3): 163-167.

Santarém VA, Rubinsky-Elefant G, Ferreira, MU. Soil-transmitted helminthic zoonoses in humans and associated risk factors. In: Pascucci S. Soil contamination. Rijeka: InTech; 2011. p. 43-66. PMid:19551291. http://dx.doi.org/10.1590/S0036-46652009000300007

Tiyo R, Guedes TA, Falavigna DL, Falavigna-Guilherme AL. Seasonal contamination of public squares and lawns by parasites with zoonotic potential in Southern Brazil. J Helminthol 2008; 81(1): 1-6. PMid:18053297 